\title{
ERRATUM
}

\section{Erratum to: Erythema of Rosacea Impairs Health- Related Quality of Life: Results of a Meta-analysis}

Anthony Bewley $\cdot$ Joseph Fowler $\cdot$ Helmut Schöfer $\cdot$ Nabil Kerrouche $\cdot$

Vincent Rives

To view enhanced content go to www.dermtherapy-open.com

Published online: March 30, 2016

(c) The Author(s) 2016. This article is published with open access at Springerlink.com

Erratum to: Dermatol Ther (Heidelb)

DOI 10.1007/s13555-016-0106-9

In the original publication the Funding section incorrectly states that funding was received from Galderma UK. This should state that funding was received from Galderma.

Open Access. This article is distributed under the terms of the Creative Commons AttributionNonCommercial 4.0 International License (http://creativecommons.org/licenses/by-nc/4.

The online version of the original article can be found under doi:10.1007/s13555-016-0106-9.

\footnotetext{
A. Bewley $(\square)$

Whipps Cross University Hospital and the Royal

London Hospital, London, UK

e-mail: anthony.bewley@bartshealth.nhs.uk

J. Fowler

University of Louisville, Louisville, KY, USA

H. Schöfer

Universitätshautklinik, Klinikum der Goethe

Universität, Frankfurt am Main, Germany

N. Kerrouche

Galderma R\&D, Sophia Antipolis, France

V. Rives

Galderma International, Paris, France
}

0/), which permits any noncommercial use, distribution, and reproduction in any medium, provided you give appropriate credit to the original author(s) and the source, provide a link to the Creative Commons license, and indicate if changes were made. 